\title{
Pemaknaan Konten Dalam Media Sosial (Studi Pada Pengguna Aplikasi Bigo Live Di Kalangan Mahasiswa Jurusan Ilmu Komunikasi)
}

\author{
Stella Kesuma, Lusia Savitri Setyo Utami \\ Stella.915160006@stu.untar.ac.id,Lusias@fikom.untar.ac.id \\ Fakultas Ilmu Komunikasi Universitas Tarumanagara
}

\begin{abstract}
This research discusses the meaning of content on social media, especially in the Bigo Live application. This social media still has some negative content so it attracts a lot of attention. Researchers chose Bigo Live because this application has a strong interaction with its users. The purpose of this study is to describe the meaning of the audience of the content in Bigo Live. The theory used in this research is reception analysis theory with qualitative research methods. Analysis of the Reception Study uses the criteria of media text readers namely Dominant Reader (dominant hegemonic position), Negotiated Reader (negotiated code / position), and Opposition Reader (operational code / position). Based on the results of the analysis and discussion of the meaning of audiences on content in Bigo Live social media, the audience belongs to the negotiated position category.
\end{abstract}

Keywords: Mass Communication, meaning, reception, social media.

\begin{abstract}
Abstrak
Penelitian ini membahas tentang pemaknaan konten di media sosial khususnya di aplikasi Bigo Live. Media sosial ini masih memiliki beberapa konten negatif sehingga menarik banyak perhatian. Peneliti memilih Bigo Live karena aplikasi ini memiliki interaksi yang kuat dengan penggunanya. Adapun tujuan penelitian ini untuk mendeskripsikan pemaknaan khalayak terhadap konten yang ada di dalam Bigo Live. Teori yang digunakan dalam penelitian ini adalah teori analisis resepsi dengan metode penelitian kualitatif. Analisis Studi Resepsi menggunakan kriteria pembaca teks media yaitu Pembaca Dominan (dominant hegemonic position), Pembaca Negosiasi (negotiated code/position),dan Pembaca Oposisi (operational code/position). Berdasarkan hasil analisis dan pembahasan pemaknaan khalayak terhadap konten dalam media sosial Bigo Live, khalayak tergolong kategori negosiasi (negotiated position).
\end{abstract}

Kata Kunci: komunikasi massa, media sosial, pemaknaan, resepsi.

\section{Pendahuluan}

Media sosial adalah wadah buat penggunanya untuk berinteraksi antar sesama pengguna lain serta memamerkan eksistensi diri. Selain itu, media sosial juga dapat dijadikan tempat untuk membagikan kegiatan atau aktivitas penggunanya. Dalam melakukan pembuatannya, pengguna juga tidak serta tanpa batasan ruang dan waktu bagi pengguna dapat mengakses media sosial dalam kurun waktu 24 jam nonstop sehingga akan membuat penggunanya menjadi candu. 
Secara garis besar, akibat dari penggunaan media sosial dapat berdampak kepada karakteristik masyarakat dan berubahnya gaya komunikasi. Dari sekian banyak media sosial, sebagai salah satu contoh yang akan diteliti adalah Bigo Live. Bigo Live adalah aplikasi live streaming (broadcasting video) yang dapat diakses langsung dari smartphone. Bigo Live ini merupakan sarana untuk memarken aktivitas diri dengan menggunakan kamera secara langsung agar dapat dijangkau oleh pengguna Bigo Live lainnya pada saat bersamaan. Seorang broadcaster (Host) Bigo Live bisa melakukan streaming dengan menunjukkan talenta dan kemampuan lain mereka serta menyiarkan kehidupannya untuk menarik khalayak dalam membangun penggemar.

Tingginya antusiasme konsumen lokal berakibat besarnya potensi untuk penyalahgunaannya. Bigo Live juga persis layaknya media sosial lainnya yang menyimpan potensi besar dalam hal-hal yang menyerempet ke arah seks dan pornografi. Dapat dicari dan dilihat di YouTube terdapat bukti siaran Bigo Live dan beberapa situs lainnya yang mencatat bahwa Bigo Live memiliki konten yang mengarah ke topik tersebut yang disebabkan oleh maraknya konten negatif di dalamnya. Saat itu juga Bigo Live membuat fitur kontrol usia dan proaktif dalam memberikan teguran untuk broadcaster yang menyajikan konten dengan muatan vulgar yang mengarah ke pornografi. Sampai saat penelitian ini dibuat, pemerintah Indonesia yang reaktif masih belum melarang Bigo Live untuk berada di Indonesia karena masih banyaknya konten negatif dan sampai saat ini pengawasan di Bigo Live semakin diperketat terutama dalam hal yang melanggar peraturan dengan menyiarkan konten negatif maka akan diberikan sanksi banned pada akun Bigo Live yang menyiarkan konten vulgar tersebut dari pusat dan tidak diperkenankan untuk melakukan live streaming kembali (CNN, 2019).

Kementerian Komunikasi dan Informatika (Kominfo) menyatakan bahwa masih ada konten negatif di Bigo Live sampai sekarang (Indotelko, 2019). Walaupun pihak Bigo ada pengawasan dan sanksi tegas untuk yang melanggar, tidak membuat para host takut dalam melakukan live streaming yang mengarah ke seks dan pornografi khususnya host perempuan. Hal tersebut masih dilakukan hanya untuk meramaikan room host tersebut agar para penggunannya yang menonton konten tersebut terpancing sehingga memberikan imbalan berupa gift semata.

Berdasarkan latar belakang tersebut, peneliti memilih menganalisa pengguna media sosial Bigo Live karena ingin mengetahui pemaknaan pada konten negatif yang ada dalam media sosial Bigo Live terutama di kalangan mahasiswa ilmu komunikasi. Peneliti mengangkat permasalahan ke dalam judul sebagai berikut: "Pemaknaan Konten dalam Media Sosial" (studi pada pengguna aplikasi Bigo Live di kalangan mahasiswa jurusan Ilmu Komunikasi). Peneliti memilih mahasiswa jurusan ilmu komunikasi karena mahasiswa ilmu komunikasi mempelajari tentang media komunikasi dan kontennya.

Penulis akan mencari tahu pemaknaan konten dalam media sosial Bigo Live. Landasan teoritik yang penulis gunakan untuk meneliti hal tersebut yaitu pemaknaan, analisis resepsi dan media sosial. Makna adalah suatu praktik konstruksi dan produksi sosial. Makna tidak mudah dianggap reproduksi dalam bahasa tapi makna adalah pertentangan sosial (social struggle), sesuatu hal untuk meraih rencana. Maka dapat disimpulkan perbedaan pemaknaan merupakan tempat masuknya bahasa di dalamnya. (Sobur, 2011). Makna dapat dibagi menjadi dua jenis yang pertama adalah makna denotatif dan keduanya adalah makna konotatif (Sobur, 2011). Analisis resepsi adalah teori yang lebih memperhatikan tanggapan dari khalayak terhadap teks. Ada tiga hipotesis dalam memaknai isi dari media yang dimiliki oleh khalayak, yaitu posisi 
hegemonik-dominan (dominant-hegemonic reading), posisi yang dinegosiasikan (negotiated reading) dan posisi oposisional (oppositional reading) (Hall, 2011). Media sosial adalah wadah buat pengguna agar dapat merepresentasikan diri sampai dengan berinteraksi, maupun bekerja sama, sekaligus berbagi dan berkomunikasi serta sebagai pembentuk ikatan viral (Nasrullah, 2017).

\section{Metode Penelitian}

Metode dalam penelitian ini adalah fenomenologi dengan pendekatan kualitatif. Fenomenologi sering difokuskan dalam memahami, menafsirkan dan menggali arti peristiwa, fenomena serta kaitannya dengan khalayak biasa terhadap keadaan tertentu (Yusuf, 2015). Adapun tahapan perencanaan dan pengumpulan data dalam fenomenologi. Tahap perencanaan digunakan agar penulis dapat mempersiapkan daftar dokumen dan pertanyaan serta menjelaskan latar belakang dan memilih informan sedangkan pengumpulan data dilakukan melalui wawancara (Kuswarno,2009). Selanjutnya, penelitian yang menggunakan metode deskriptif kualitatif memiliki tujuan untuk mencari dan menilai kelemahan dari penelitian kuantitatif (positivisme berlebih) dan penelitian ini memiliki tujuan agar bisa menggambarkan, meringkaskan berbagai jenis keadaan sampai dengan situasi, atau juga berbagai jenis peristiwa yang ada di masyarakat (realitas sosial) yang menjadi objek dalam penelitian, dan berupaya untuk mengambil realitas ke permukaan sebagai suatu ciri, karakter, sifat, model, tanda, atau gambaran tentang kondisi, keadaan, ataupun peristiwa tertentu (Bungin dalam Montana, Loisa, \& Utami, (2018) memungkinkan penulis untuk menggali dan memahami mengenai pemaknaan konten dalam media sosial (Bigo Live).

Teknik pengumpulan data yang dilakukan penulis adalah dengan melakukan wawancara, observasi dan studi kepustakaan. Wawancara dilakukan karena penulis ingin penelitian ini mendapat jawaban dan pernyataan langsung dari narasumber dan penulis ingin melihat secara langsung gerak tubuh narasumber saat sedang diwawancarai. Penulis mewawancarai mahasiswa ilmu komunikasi yang menggunakan Bigo Live dengan level 12 ke atas dan berusia 19-23 tahun. Observasi dilakukan dengan pengamatan langsung (observasi langsung) merupakan pengambilan data tanpa adanya pertolongan alat alias menggunakan mata (Nazir, 2011). Dan studi kepustakaan dengan menggunakan buku-buku referensi di perpustakaan hanya pada bagian yang diinginkan dan penting saja (Nazir, 2011). Hal ini guna memperkuat dan memperkaya penelitian penulis. Sebagai upaya melengkapi penelitian ini maka penulis menggunakan teknik pengolahan dan analisis meliputi reduksi data, display data dan verifikasi atau penarikan kesimpulan (Moleong, 2009). Lebih lanjut, untuk teknik keabsahan datanya penulis memakai teknik triangulasi. Triangulasi adalah sebuah teknik pengumpulan data yang digunakan untuk menemukan interpretasi data sekaligus temuan yang lebih kredibel dan lebih akurat. (Yusuf, 2015)

\section{Hasil Penemuan dan Diskusi}

Penulis mewawancarai pengguna Bigo Live mengenai tanggapan mereka terhadap berbagai konten untuk mengetahui makna denotatif dan makna konotatif dengan mulai menilai dari konten positif sampai konten negatif di Bigo Live. Menurut pengguna Bigo Live, konten yang positif adalah konten yang bersifat membangun dan 
menghibur sehingga melalui konten tersebut para pengguna mendapatkan teman baru dan pengetahuan baru. Sedangkan menurut pengguna, konten yang negatif adalah konten yang memuat unsur pornografi seperti memakai baju tidak senonoh sehingga memamerkan sebagian tubuhnya yang tidak patut dilihat banyak orang sampai dengan mengeluarkan suara-suara yang tidak enak untuk mereka dengar (misal: desahan). Menurut Kerad (Sobur, 2011) makna dibedakan menjadi makna denotatif dan juga makna konotatif. Makna denotatif merupakan kata yang tidak memiliki perasaan sampai makna tambahan, lalu makna konotasi atau biasa disebut dengan konotatif adalah sebaliknya, yaitu makna yang memiliki arti perasaan dan tambahan tertentu sampai dengan nilai emosional tertentu disamping makna dasar umumnya.

Dari wawancara tersebut penulis merangkum bahwa makna yang diterima oleh ketiga informan mengenai konten positif yang ada di Bigo Live tersebut termasuk kedalam kategori makna denotatif karena dari jawaban informan penulis dapat melihat pandangan pengguna mengenai informatif atau tidaknya sebuah konten. Selain itu, penulis mengambil kesimpulan dari ketiga informan Bigo Live yang diwawancarai bahwa konten yang memiliki makna positif dalam Bigo Live akan berdampak positif juga bagi pengguna Bigo Live, begitu juga sebaliknya jika suatu konten yang memiliki makna negatif maka akan berdampak negatif juga.

Penulis merangkum bahwa menurut ketiga informan mengenai konten yang positif di Bigo Live harus terus ada karena gunanya untuk menghibur dan agar sesuai dengan penggunaannya yaitu untuk hal positif. Hal ini membuktikan bahwa tujuan dari pembuatan Bigo sudah sesuai dengan apa yang diharapkan karena pengguna Bigo Live memiliki pendapat yang sama mengenai Bigo Live yaitu berinteraksi dengan pengguna lain sehingga mereka mendapatkan teman baru.

Adapun berbagai jenis makna denotatif diantaranya adalah makna denotasional, makna kognitif, makna konseptual, makna ideasional, makna referensial atau makna proposisional. Disebut demikian karena makna ini merujuk (denote) kepada suatu referen, konsep, atau ide tertentu dari suatu referen.

Sedangkan makna kognitif berarti makna tersebut menyangkut kepada kesadaran atau pengetahuan sampai dengan stimulus (dari pihak pembicara) dan respons (dari pihak pendengar) serta berkaitan dengan hal yang dapat diserap pancaindra (kesadaran) dan rasio manusia. Maka makna ini disebut juga sebagai makna proporsional karena berisi hal yang bersifat faktual meliputi informasi atau pernyataan. Makna tersebut yang diacu dengan berbagai jenis nama, adalah makna yang paling dasar pada suatu kata (Sobur, 2011).

Selain menanyakan ketiga informan Bigo Live mengenai makna sebuah konten yang positif dilihat hasil dari wawancara, penulis juga tertarik untuk menanyakan ketiga informan mengenai konten yang negatif.

Beberapa istilah dari makna konotatif diantaranya adalah makna konotasional, makna emotif atau disebut dengan makna evaluatif. Makna konotatif adalah suatu jenis makna di mana stimulus dan respons mengandung nilai-nilai emosional. Sebagian makna konotatif terjadi dikarenakan pembicaranya yang ingin menimbulkan perasaan setuju-tidak setuju, senang-tidak senang, dan sebagainya pada pihak pendengar dan di pihak lain, kata yang dipilih itu memperlihatkan bahwa pembicaranya juga memendam perasaan yang sama (Sobur, 2011).

Dari hasil wawancara dengan para ketiga informan Bigo Live maka penulis menarik sebuah kesimpulan bahwa makna yang diterima oleh informan mengenai konten negatif tersebut termasuk kedalam kategori makna konotatif karena dari jawaban mereka penulis dapat melihat emosional mereka tentang konten tersebut. 
Penulis menyimpulkan bahwa ketiga informan Bigo Live merasa bahwa konten yang negatif itu tidak baik untuk dilihat banyak orang karena membuat pengguna merasa tidak nyaman maka dari itu konten yang bermakna negatif harus langsung ditindak lanjuti ataupun yang biasa disebut dengan report agar tidak banyak pengguna yang dapat melihat konten negatif tersebut guna untuk memberikan kenyamanan bagi pengguna. Hal ini membuktikan bahwa tujuan dari Bigo sudah sesuai dengan apa yang diharapkan karena ketiga informan telah berpartisipasi aktif dalam bentuk mereport konten yang bermakna negatif pada saat menonton videonya.

Walaupun banyaknya berbagai macam jenis konten di Bigo Live mulai dari konten yang negatif hingga konten yang positif tetap saja ketiga informan menginginkan sebuah konten yang positif sehingga dapat membawa dampak yang positif bagi penggunanya yang melihat konten tersebut.

Berdasarkan pemaknaan informan maka akan timbul sebuah resepsi. Maka dari itu, penulis terdorong untuk ingin mengetahui lebih dalam bagaimana cara informan memaknai sebuah isi dari media Bigo Live tersebut.

Menurut Hall (Hall, 2011), ada tiga jenis hipotesis dalam memaknai isi media yang dapat dimiliki khalayak, antara lain:

1. Posisi hegemonik-dominan (dominant-hegemonic reading): pembaca sejalan dengan kode-kode program (yang didalamnya terkandung sikap, nilai, asumsi dan keyakinan) dan menerima secara penuh makna yang diberikan dan diinginkan oleh pembuat program .

2. Posisi yang dinegosiasikan (negotiated reading): pembaca berada pada batasbatas tertentu sejalan dengan kode-kode program dan pada dasarnya menerima makna yang diberikan oleh pembuat program, tetapi mengubahnya sedemikian rupa sehingga menjadi posisi yang sesuai dengan minat pribadinya.

3. Posisi oposisional (oppositional reading): pembaca secara penuh tidak sejalan dengan kode-kode program dan menolak secara penuh makna pembacaan yang diberikan lalu kemudian menentukan alternatifnya sendiri dalam menginterpretasikan atau memaknai pesan sehingga sesuai dengan posisi yang diinginkan.

Tujuan dari pembuatan bigo itu agar semua pengguna yang menonton videonya dapat berpartisipasi aktif sehingga anda dapat memberi pendapat melalui obrolan dan berinteraksi dengan pengguna lain serta orang yang sedang bersiaran langsung.

Walaupun banyaknya konten negatif di Bigo Live menurut para informan tetap saja tujuan dari Bigo Live sendiri sudah sejalan karena menebar hal positif dan Bigo Live sendiri banyak dimanfaatkan untuk hal positif seperti mencari teman, berinteraksi dengan orang baru, mendapatkan wawasan baru, dan berpartisipasi aktif antar sesama pengguna. Hanya saja ada beberapa oknum atau orang atau individu yang tidak berpartisipasi dengan tujuan Bigo tersebut dengan munculnya konten-konten yang negatif.

Dalam hal ini ketiga informan termasuk kedalam kategori posisi yang dinegosiasikan (negotiated reading): pembaca dalam batas-batas tertentu sejalan dengan kode-kode program dan pada dasarnya menerima makna yang diberikan oleh pembuat program, namun mengubahnya sedemikian rupa sehingga mencerminkan posisi dan minat pribadinya. Jika melihat dari kriteria informan sebagai mahasiswa jurusan Ilmu Komunikasi. Posisi negosiasi ini dapat disebabkan karena adanya kesadaran dan pengetahuan informan mengenai konten media sosial dan implikasinya pada khalayak. 


\section{Simpulan}

Melalui penelitian ini, penulis merangkum hasil penelitian dan dapat disimpulkan bahwa makna yang diterima oleh pengguna Bigo Live mengenai konten positif termasuk ke dalam kategori makna denotatif karena memberikan hal yang bersifat informatif bagi mereka. Sedangkan makna yang mereka terima mengenai konten negatif termasuk ke dalam kategori makna konotatif karena melibatkan perasaan dan emosi setelah pengguna melihat konten negatif tersebut yang berakibat pada tindakan melaporkan dan menindaklanjuti konten tersebut di Bigo Live. Analisis resepsi dari pemaknaan konten dalam media sosial Bigo Live dalam penelitian ini menemukan bahwa pengguna Bigo Live ini berada dalam posisi negosiasi sebab ada sikap kompromi, yaitu menerima konten yang terdapat di Bigo Live, namun protes jika ada yang kurang sesuai. Berdasarkan kesimpulan tersebut, maka penulis menyarankan agar khalayak dapat menggunakan media sosial dengan lebih baik dan bijak lagi terutama dalam menilai dan memilih konten di media sosial.

\section{Ucapan Terima Kasih}

Dalam penyusunan skripsi ini hingga terlaksananya penyusunan skripsi ini peneliti ingin menyampaikan rasa terima kasih yang sebesar-besarnya kepada berbagai pihak yang ikut terlibat dan telah membantu peneliti selama proses penelitian langsung. yaitu kepada Tuhan YME atas berkat dan rahmat-Nya yang menyertai penulis selama proses penyusunan penelitian ini, kepada seluruh narasumber yang telah memberikan kesediaan untuk bekerja sama selama proses penelitian ini, kepada orang tua dan adik peneliti yang telah memberi dukungan tiada henti kepada peneliti baik selama proses perkuliahan maupun penelitian, kepada sahabat-sahabat peneliti yang senantiasa telah memberikan semangat dan dukungan, dan berbagai pihak lainnya yang tidak dapat disebutkan satu persatu oleh peneliti.

\section{Daftar Pustaka}

CNN Indonesia. (2019). Bigo Klaim Blokir 200 Ribu Konten Negatif. November 3, 2019. Terarsip di: https://m.cnnindonesia.com/teknologi/20190311171555192-376244/bigo-klaim-blokir-200-ribu-konten-negatif

Hall, Stuart. (2011). The work of representation: "Representation: Cultural Representations and Signifying Practices (Culture,Media and Identities series). Ed Stuart Hall Sage Publication.

Indo Telko. (2019). Konten Negatif Masih Banyak Di Bigo. Maret 12, 2019. Terarsip di: http://www.indotelko.com/read/1552363808/konten-negatif-bigo

Kuswarno, Engkus. (2009). Metode Penelitian Komunikasi : Fenomenologi, Konsepsi, Pedoman dan Contoh Penelitiannya. Bandung: Widya Padjadjaran.

Moleong, Lexy J. (2009). Metode Penelitian Kualitatif. Bandung: Remaja Rosdakarya Montana, Osbert, Loisa, Riris, \& Utami, Lusia Savitri Setyo. (2018). Masyarakat dan Kearifan Budaya Lokal (Bentuk Pela Masyarakat di Negeri Batu Merah Kota Ambon Pasca Rekonsiliasi). Jurnal Koneksi. 2 (2). 507-514. Desember, 2018. Terarsip di: https://journal.untar.ac.id/index.php/koneksi/article/view/3930/2313

Nasrullah, Rulli. (2017). Media Sosial : Perspektif Komunikasi, Budaya, dan Sosioteknologi. Bandung: Remaja Rosdakarya. 
Stella Kesuma, Lusia Savitri Setyo Utami: Pemaknaan Konten dalam Media Sosial (Studi pada Pengguna Aplikasi Bigo Live di Kalangan Mahasiswa Jurusan Ilmu Komunikasi)

Nazir, Mohammad. (2011). Metode Penelitian. Jakarta: Ghalia Indonesia

Sobur, Alex. (2011). Analisis Teks Media. Bandung: PT Remaja Rosdakarya.

Yusuf, Muri. (2015). Metode Penelitian : Kuantitatif, Kualitatif dan Penelitian Gabungan. Jakarta: Kencana Prenada Media Group 